DOI: 10.20472/AHC.2017.002.004

\title{
GEORGE MCMILLAN
}

Aegis Defense Services, United States

\section{A UNIFIED THEORY AND THE FIFTH ERA OF PHILOSOPHY}

\begin{abstract}
:
This paper argues that since the three barriers of achieving a unified theory of the behavioral sciences as described by Gintis 2009 was achieved in two previous papers; and the field of philosophy can readily be placed into a hypothetico-deductive modeling standards to meet the criteria of Popper 1952 and Homans 1964; and can be placed into a Cartesian modeling format to meet the criteria of Harsanyi 1971 in the same papers, then all of the major abstract concepts explained by the text of Leo Strauss and Josephy Cropsey have already been systematized into a qualitative modeling format as the precursor to linking the model to existing economic and demographic statistical models, then the Fifth Era of Behavioral Scientific Philosophy has already begun by the interdisciplinary economic and social sciences.
\end{abstract}

\section{Keywords:}

Unified Theory, Unification of the behavioral sciences. Fifth Era of Philosophy.

JEL Classification: B12, A12, E03 
Introduction: The Objectives of the Strauss-Cropsey text and the Fifth Era of Philosophy

\section{Growth of World Population and the History of Technology}

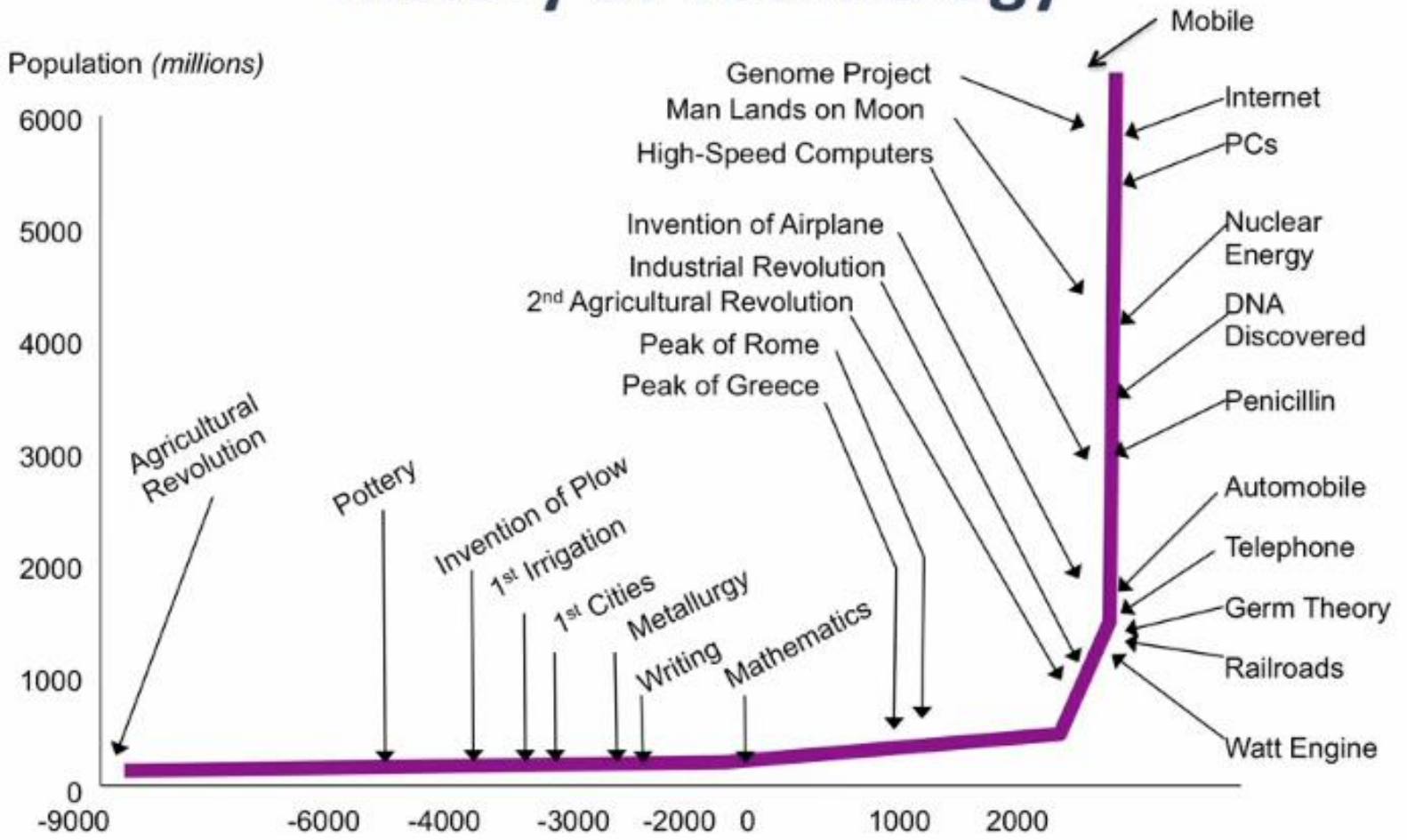

Source: Milken Institute, Robert Fogel/University of Chicago

The objective Strauss-Cropsey text History of Political Philosophy (1987) can be said to transform the entire discipline of Philosophy from the present concurrent Third Era of Enlightenment Era thought, and the Fourth Era of post-modern decontructionalism of Derrida, into a Fifth Era of Behavioral Science.

In the previous papers, McMillan 2015 and McMillan 2017, the unified theory of the primary philosophical and social sciences was based on the idea of devising a method to extend the post Darwinian Integrated Causal Model (ICM) presented in Barkow, Tooby and Cosmides in The Adapted Mind (1992), throughout the philosophical and social sciences.

The essential aspect of the research design presented in the previous papers is summarized by the contrasting of the only two teams to have developed a coordinated foundational, political and economic series of philosophical theories. The two teams were David Hume and Adam Smith, which were subsequently opposed by the works of Karl Marx and Friedrich Engels. The causal axis continuum dichotomy system is summarized below, while the primary series of psychological, political and economic set of frameworks that comprise the dual independent variable system are summarized midway through the paper. 


\section{The Hume-Smith three axis system}

The Hume-Smith system is represented in a Cartesian format in the foundational-politicaleconomic order by the following process.

- The X-axis represents the gradation of empathy/sympathy versus non empathy/sympathy in a continuum.

- This is the precursor to cooperative people (i.e. proper form of positive-sum games) and antagonistic personalities (i.e. zero-sum games and negative-sum disruptive or sabotage mind sets and behaviors).

- The Y-axis continuum represents the method of mass political organization and the level (or trade-off) of constructive versus destructive competition for resources and mates, or mass antagonism or cooperation, engendered by the type of government form and the elite-mass relations tendencies.

$\circ \quad$ Their theories are consistent with Aristotle's 6 Forms

- The value neutral Forms of:

- The rule of the one

- The rule of the few

- The rule of the many

- The Proper Forms of:

- Monarchy

The Perverted Form of:

- Aristocracy

Tyranny

- Constitutional Polity

Oligarchy

Mob Rule Democracy

- The Z-axis represents economic growth versus nongrowth continuum in relationship to a growth versus equity dichotomy in the fundamental per-capita GNP ratio of $\mathrm{C}+\mathrm{I}+\mathrm{G} / \mathrm{n}$ people

- (consumer spending, investment, government spending/n-people, i.e. economic growth rates of change over demographic rates of change)

- The idea here is to relate the model to the two persistent trends of technology and population growth.

- The following outcome measure sub-model is designed to link the primary axis continuum set and variable set to the outcome measure system to specify the real world set of applicability.

- This is achieved by transitioning the existing First, Second and Third World category system into a four-category system by adding a Fourth World failed state corrupt autocratic leader cleptocracy category.

- This trend has become to dominate the entire content of Saharan and sub Saharan Africa, much of the Middle East and Central Asia, where it is commonly referred to as the 'resource curse' phenomenon.

- It should also be said that much of Latin America, especially Central America, is steadily moving from the Third World category into the Fourth World failed state category phenomenon due to the dominance of the narco-traffickers in corrupting the political systems by bribing key politicians, judges, the military, police and executing journalists who report it. 
- This new four category system is based on having its own three axis $(X 2, Y 2, Z 2)$ outcome measure sub-model system that connects to the primary $(X, Y, Z)$ axis sub model.

- In the outcome measure submodel:

- The vertical Y2 axis represents a low to high economic growth continuum.

- The horizontal X2 axis represents a low to high population growth over time continuum. This is done to devise a globally utopian versus dystopian dichotomy continuum, based on applying the market theory of wage labor determination on a global singular market scale to form a wage labor equality versus inequality continuum.

- It is the contention of this method of analysis that as global population continues its upward climb, then global wage labor equity will steadily decline in the First and Second Worlds towards a declining equilibrium point of the Third and Fourth Worlds.

- The horizontal Z2 axis then becomes a low to high 'human capital' education and training continuum as understood in the discipline of economics. The purpose of this continuum is to link to the mathematics of the dependent variable and outcome measure system to the complex behavioral system represented by the primary $(X, Y, Z)$ axis continuum.

\section{The Marx-Engels three axis system}

The Marx-Engels system is represented in a cartesian format in the foundational-politicaleconomic order by the following process.

- The $X$ axis represents the level of destructive self-interest versus collective interest

- Destructive self-interest is elicited by:

- Corruption occurs because of Patriarchal nepotism and familial ruling dynasties via

- property rights for subjugation of the lower classes

- marital rites to subjugate women

- market driven competition that leads to monopolies and oligopolies

- The hypothetical cure was hypothesized to be the level of altruism elicited in a noncompetitive, nonmarket system without property rights or marital rites.

- The $Y$ axis represents the level of antagonism versus cooperation engendered by the government form and the elite-mass relations tendencies

- but is derived from Plato's conception of communism and the quest for an enduring state in The Republic

- (Plato reverted to a cyclical government Form model in The Laws, due to the impracticality of the ideas of Children in common in The Republic.)

\section{Elimination of the Marx-Engels Hypothesis}

As McMillan 2015 explained, the Marx-Engels model can be eliminated on all foundational, political and economic philosophical levels. In this paper, the human beings in both the 
Democratic and capitalism system and the Communist system maintained the shared core motivational drives of: self-survival and survival of the species as the two primary unseen noumenal forces of nature based on Darwin's evolutionary theory; which relate to 0 the observable phenomenon of the pursuit of resources and mates used as the two motivations in anthropology, and the pursuit of economic gain (Downs 1957) and social status (Veblen 18XX) as advocated by Harsanyi (1969).

The purpose of using this string of twin motivational drives is first to meet the requirement of the Strauss Cropsey text that the nomos-physis variation is based on the determination of the noumenal 'unseen forces of nature' which accounts for nomos, i.e. the laws of nature, as it relates to observable phenomenon of human activity, which correspond to the pursuit of resources and mates used in anthropology, and economic gain and social status used in political economy, which are parallel concepts already in use that are applicable to a wide range of disciplines.

The existence of these parallel concepts represents the underlying motivations and therefore the means of laterally integrating the series of evolutionary theories, with the social sciences of psychology, politics and economics, via the core and periphery method of theorizing used in psychological personality theories as explained by Maddi 1972. The existence of parallel underlying motivations and the feasibility of the lateral integration of empirical cross disciplinary frameworks makes the operationalizing of the nomos-physis distinction feasible.

\section{Understanding Core similarities and Periphery differences in behavioral dynamics}

In the core-periphery method of theorizing it is the value neutral shared motivations and observable activities which are referred to as the core behaviors common to all peoples and cultures. The differences in behavior in terms of their constructive or destructive outcomes is termed the periphery of behavior and was originally represented in a Proper Form and Perverted Form dichotomy of the Ancient Greeks, and especially Aristotle in terms of the model being presented here.

The parallel relationship between the core-periphery method of behavioral modeling and Aristotle's system is important to understand as McMillan 2015 explained, as the core-periphery method of was used to analyze the core similarity of both Capitalist and Communist societies and ascertain what the peripheral difference was.

The core aspect of behavior was that the people driven by the twin motivations of self-survival and survival of the species derived from evolutionary theory, via the observable behavior of pursuing resources and mates, or economic gain and social status as mentioned earlier. However, in the communist system the bureaucrats used their position of power to give themselves an advantage in the pursuit of resources to attract wealth, power and women, and this system of pursuing economic gain and social status produced a dismal behavioral economic dynamic stemming from this political arrangement. The result was that the bureaucratic system created a destructive competition in the pursuit of technical innovation and mass manufacturing product technology innovation cycles when the entrepreneurs had to beg for resources from the bureaucrats.

In contrast, the West leaped ahead drastically as the Kennedy and Johnson administrations followed National Security Council Resolution \#68 and poured immense investment into the 
military industrial complex and placed a premium on advancing key technical projects in the nuclear, aerospace, communications, surveillance and code breaking endeavors. So far researchers tend to focus on the things that were produced, rockets, missiles, guidance systems, jet aircraft, tanks that can shoot accurately on the move, personal computers, flat screen television monitors, and mobile phones are just some of the items, the list is almost endless.

However nice the products are, this method of analysis moves the focusing from the 'things' that were developed, to the constructive versus destructive behavioral dynamic instead. The constructive behavioral dynamic that NSC \#68 created was a fierce constructive competition between rival engineering universities and competing commercial companies where the prize was large government contracts to develop cutting edge future generational products for geopolitical advantage in one sense, with immense secondary commercial applications in a second sense. The companies that produced the better products were typically selected as the contractor, and these tactical military products tended to have immense practical consumer applications later in the development cycle.

This strategy of the Kennedy administration's NSC \#68 policy was later replicated with great results by the Reagan, Bush, and Clinton administrations. The technical advancement cycle drastically increased in speed, where the next generational product was progressing from a new design phase, to a cutting-edge product for the government, to wealthy citizens who desired the latest products for exclusivity and social status, and finally to mass production for the mass consumer to enjoy from discount chain stores.

To understand what NSC \#68 did, one just has to understand that the disciplines of engineering an physics went from using slide rules to makes calculations, and blue prints for making designs, to using calculators, computer numerically controlled machine tools, and later computer aided design, and computer aided machines, and is now integrating and advancing these concepts into three dimensional printing in plastics this decade, to three dimensional printing in metals by the next decade. The combination of advances and integration technologies has decreased the design, prototype, first generation, to next generational cycle, from roughly a 30 year timespan at the beginning of the $20^{\text {th }}$ century, down to less than a 10 year time span at the end of the $20^{\text {th }}$ century.

Computers, encrypted radios, mobile phones, flat screen television monitors and the internet were all advanced in this manner from initial government investment that generated university and commercial competition on multiple sectors simultaneously, resulted in a self-sustaining private sector dynamic as well that fed the production design, manufacturing and consumer feedback loop cycles studied by economics.

The geopolitical result was that the Communist systems in Eurasia were falling so far behind that they could no longer reverse engineer products to keep pace with the Western dynamic, and had to switch to market economies as a direct result of the NSC \#68 strategy of the Kennedy and Reagan administrations. This is a phenomenon that is widely discussed in the discipline of economics and under discussed by the soft social sciences in the post-modern deconstructionalist era that were decidedly disappointed that the utopian socialist dream of Communism in Eurasia ended in disaster, and as a result, transitioned to the "third way" of redistributive socialism as their 'way forward.' 


\section{Applicability of the core-periphery method in behavioral science}

The aspect of note here, is that the use of the core-periphery method of theorizing developed in the discipline of psychological personality theories was adapted to the behavioral analysis of Capitalism and Communism. It is this use of the core-periphery method of analysis that generated the understanding of the peripheral behavioral aspect of the competing political-economic ideological systems.

It is this behavioral differentiation that explains the constructive competition in Capitalism, where the same human drives generated a destructive behavioral dynamic in the Communist bureaucratic system. It is this core-periphery behavioral analysis that allows for the common casual theme of the human studies to be derived from Vernon Smith's non-centrally controlled capitalism versus centrally controlled communism continuum dichotomy (which operationalized the invisible hand concept of Adam Smith into a measurable idea).

Vernon Smith's continuum dichotomy explains the constructive versus destructive behavioral dynamic that either facilitates the Kondratiev cycles and speeds up the design, prototype, first and future generational cycles of a product in a free market system, and how the Communist system debilitates the Kondratiev cycles in the advancement of technology, labor productivity growth and total output in terms of Baumol's sectoral development theory. This series of understandings then becomes the basis for establishing the nomos-physis variation in the field of philosophy in general, and indeed all of the social sciences, in the development of a core integrated explanatory model of the human studies.

\section{Creating a System of Optimums and Suboptimum extremes}

It is this recognition of Vernon Smith's noncentrally controlled constructive behavioral dynamic versus the centrally controlled destructive behavioral dynamic that becomes the basis of linking comparative economic analyses to Aristotle's Six Forms of government, to the various facilitative versus debilitative psychological personality theories of Maddi, Fromm, Rogers, Maslow and others. The working premise here is that the utopian ideal state would be an amalgamation of constructive facilitative psychological, political and economic behavioral dynamics, i.e. a system of optimums. In contrast the dystopian worst state would be an amalgamation of destructive debilitative minimal behavioral dynamics, i.e. a system of extreme sub optimums.

The combination of this alignment of psychological, political, and economic frameworks along a constructive versus destructive working hypothesis, gleaned from Aristotle's Proper and Perverted Form method of core-periphery modeling of ancient cultures, confirms the autonomy versus heteronomy, or the internal locus of control versus external locus of control dichotomy, of Kant as the overarching causal theme of the philosophical and social sciences.

It is the overarching causal theme of the philosophical and social sciences that is the nomosphysis variation of the Ancient Greeks which can now be defined with a series of $20^{\text {th }}$ Century frameworks that confirm Kant's philosophical hypothesis. It is important to understand that the overarching causal system is synonymous with the nomos-physis variation of Ancient Greek classical philosophy. 
Secondly, the overarching causal theme of the micro and macro social sciences only becomes discernable with the value neutral bifurcated constructive versus destructive behavioral Form method of integrative modeling found in (a) the core-periphery method of modeling in the analysis of competing psychological personality theories by Maddi, which is (b) parallel to the Proper and Perverted Forms of Aristotle, which is (c) parallel to the virtuous and vicious cycles of macroeconomic theory. All three areas of psychology, Greek political philosophy, and contemporary neoclassical economic theory have a means of describing a functional versus dysfunctional behavioral dynamic respective to their areas of study. This similarity of modeling made it possible to compare ideological systems which was the subject matter of McMillan 2015, and this series of papers in 2017.

The end result, is that this system, can operationalize Plato's concept of Forms, represented in a cartesian modeling format of the triple set of the Hume-Smith $(X, Y, Z)$ causal axis continuums, and the series of psychological personality theories expressed by Maddi 1972, as they relate to Aristotle's six form of Government, as they both relates to the constructive virtuous versus the destructive vicious economic behavioral dichotomies, which are signified by the per capita GNP ratio simplification explained in the previous papers. An outline of the system will be presented here as a quick reference guide.

\section{The Selection of the dual independent variable system frameworks}

The Value Neutral System Constant is represented in terms of the triple set of dual motivations ranging from:

- Self-survival and survival of the species in evolutionary theory,

- to the pursuit of resources and mates in anthropological theory,

- and the pursuit of economic gain and social status in political economy.

- This set of cross cultural common instinctual drives and emotional motives spans the range of biological studies and evolutionary theory across the full range of the social sciences spectrum.

The Initial Micro Behavioral Independent variable was the last element determined by the author. The criteria for making this selection derived from the Hume-Smith versus Marx-Engels comparison, and the prior knowledge of the relationship of Aristotle's Sif Forms of Governent and the per capita GNP ratio simplification in conjunction with the two central determinants of the multiplier and gini coefficients.

This element was filled with:

- Erich Fromm's biophilous-necrophilious, productive-sadomasochistic, character orientation model

- In conjunction with Maddi's (1972) core-periphery method of modeling and analysis of competing character orientation theories, which provide confirmation and clarity.

The additional criteria used to make this determination was based on the following pattern of knowledge:

- The framework had to be a third generational general framework that sought to improve upon, advance, and consolidate previous smaller frameworks.

- "Third generational models" generally follow the value neutral constant and bifurcated Proper and Perverted Forms of Behavior to match Aristotle's Six Forms of Government 
which match the virtuous versus vicious cycles in economic theory, albeit in a different terminology peculiar to the discipline.

- The framework had to come from post Freudian psychology linking Darwinian instinctual drives with Individual character orientation divisions (e.g. facilitative-debilitative)

- The framework must link to functional-dysfunctional small group social psychological theories in order to link micro behavioral theories with the macro behavioral theories and minimize gaps in the system.

The Macro Independent Variable of Aristotle's Six Forms of Government came directly from the $Y$ axis continuum of the competing foundational-political-economic philosophies of Hume-Smith versus Marx-Engels.

Macro Dependent Variable in per Capita GNP Based economic theories deriving directly from the axis continuum and prior course work.

In the early stages of the model, the complicated economic theories were boiled down to the two central determinants of the multiplier and gini coefficients and the per capita GNP ratio because:

- it is the portal to any of the major economic theories and frameworks

- it is the minimal amount of economics needed to merge with Aristotle's framework

- it simplified the complex economics theories and mathematics while serving as a placeholder allowing the author to work on the evolutionary psychology, psychological personality theories, the larger social psychology frameworks.

- The connections to the mass organizational elements of politics and economics of the system were already familiar to the author.

Per capita GNP based theories can be augmented by:

- Kondriatiev Long Wave theories explain the role of key technological innovations ushering in totally new economies approximately every hundred years or so, and not only explain long term economic phenomena, but a crucial aspect of human behavior as they pursue resources and mates, and economic gain and social status.

- Long Wave Theories encompass the time frames in which:

- economic supply and demand theories,

- development theories,

- general equilibrium theories

- endogenous growth theories

$\circ$ and the market theory of wage labor determination

$\circ$ all operate within.

- All per capita GNP based theories automatically link to existing Demographic statistical models of the time frame in question, i.e. the per capita GNP ratio can be understood as a Kondratiev/Malthusian theory framework.

The outcome measure system deriving from off-the-shelf economic and demographic models. Since the method of analysis is to advance the overarching global ideological theories, the outcome measure system links the model to the two persistent trends of technology and population growth (Kondratiev/Malthus).

- These two primary trends relate directly to the two secondary trends of:

○ the relocation of Developed country manufacturing facilities to the Developing world, 
- and the mass migration of Developing world populations to the Developed world.

- The result will be a declining equilibrium of wage labor prices infinitum due to the population trends of the developing world.

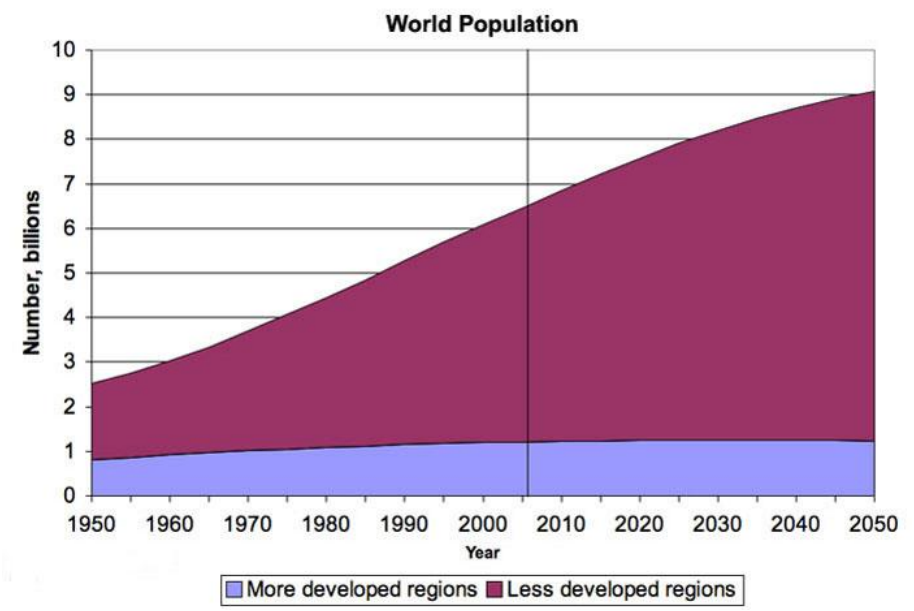

World Population Growth, 1750-2150

Population fin tilions?

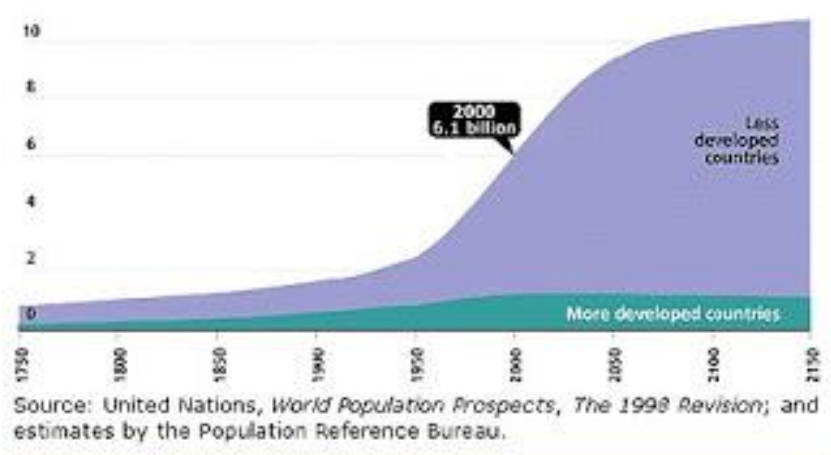

\section{The Cartesian Model and the development of a hypothetico-deductive model}

It is this cartesian modeling format of laterally integrated psychological, political and economic frameworks, the entire range of foundational-political and economic areas of the discipline of philosophy is expressed in a singular scientific hypothetitco-deductive model as previously explained. This model therefore advances the objectives of des Cartes (1752), Popper (1952), Homans (1964), and Strauss and Cropsey (1987), in such a manner that it also generates Harsanyi's concept of an integrated explanatory model (IEM).

The idea of Harsanyi was to create a "core model" of the social sciences to reduce the egregious errors of academicians in the soft social sciences of making policy prescriptions which are already known to have disastrous repercussions as measured by the discipline of economics in context of past experiments under similar conditions. 
However, the problem in the soft social sciences is that they do not use scientific factor analysis troubleshooting frameworks which account for recurring positive, or negative consequences, so they cannot judge the dynamic ripple of first, second and third order effects. How many times has highly redistributive socialism led to a series of financial hyperinflation, economic collapse and political instability, when applied under high population growth situations in Latin America and India and the soft philosophical and social sciences still do not have a model that differentiates that phenomenon from Nordic socialism which has high economic growth and low population growth? One would think that they would have a model to reflect this recurring reality, but the reality is that they do not. It is difficult not to notice that the soft social sciences in North America have been highly resistant to the performance of proper autopsies of Marxist Communism, or Marxist Social Democracy of the Latin American experiments. It would negate their message to their utopian audiences.

Due to the lack of use of schematic style analytical frameworks in the soft philosophical and social studies, they have little in the way of institutional learning over generations. It is the use of advancing empirical frameworks via scientific factor analysis models that account for the means of documenting positive and negative recurring behaviors in a schematic form. The use of schematic behavioral frameworks allows future generations of researchers to build upon and expand the theoretical frameworks as they evolve from first, to second and third generational models. It is the advancement from first to second and third generational models that advances a discipline's institutional memory and knowledge of their own subject matter.

\section{Harsanyi Core Integrated Explanatory Model (IEM)}

It is the series of analytical frameworks explained in this series of papers that represents Harsanyi's IEM and "core model" of the primary philosophical and social sciences. This expansion of analytical frameworks discussed previously represents the means of transferring the essential information from the disciplines of philosophy, psychology, and political theory to expand the models for the interdisciplinary economic and behavioral economics movements. It is the two movements of the interdisciplinary economic science and behavioral economics movements that (a) already use scientific troubleshooting schematic frameworks, and (b) wish to laterally integrate as many frameworks as possible. The natural end of this endeavor is to encompass the rest of the human studies, which is what this model achieves.

The development of the original research design was primarily to achieve three goals. First, to perform a behavioral analysis of the great ideological experiments to advance comparative political systems in the discipline of Political Theory. Secondly, it represented the means of operationalizing the abstract concept of the nomos versus physis variation of the Strauss and Cropsey text History of Political Philosophy.

This research design entailed a third goal, the fusion of political and economic frameworks, which was facilitated by the critiques of previous interdisciplinary efforts by Harsanyi 1960, 1966 and 1969. In this respect, the research design greatly expanded in scope to meet most, if not all, of the criteria Harsanyi suggested to overcome the problems of previous efforts that had vast deficiencies. For example, he criticized the effort of Talcott Parsons for not attaining the hypothetico-deductive level to become a scientific model. Harsanyi also critiqued the Rawls, $A$ Theory of Justice (19XX), for being a work of pure fantasy - the idea of achieving greater income equality by any other means other than creating the conditions for a tight wage labor market, and 
advancing investment in shared infrastructure and scientific education is a fairy tale. Yet it is the basis for the Basic Income Guarantee and Universal Income Guarantee movements in the West. Additionally, Harsanyi also critiqued the work of Sen and others in welfare for being illogical and not properly addressing the opportunity costs and tradeoffs of their policies, which would then have a negative net effect.

Harsanyi's critiques provided much insight into as to what problems were encountered in previous cross disciplinary attempts, and provided insight as to overcome the problems of past approaches and develop a comprehensive integrated explanatory model. The conclusion drawn from reading Harsanyi's criticism of previous cross disciplinary works is that either one does a massive overhaul of the foundational-political-economic philosophies of the past in order to meet the criteria of a hypothetico-deductive model, or do nothing at all. The reality is that there is simply nothing in between.

\section{Vernon Smith and the Interdisciplinary Economic Sciences}

In addition, since Vernon Smith's based his ideas of the noncentrally controlled Proper Form versus centrally controlled Perverted Form continuum dichotomy, (placed into Aristotelian terms) becomes the basis of causality of the IEM, which utilizes the ICM of Barkow, Tooby and Cosmides et. al. as an existing base from evolutionary theory.

Furthermore, since McMillan 2015 eliminated the Marx-Engles foundational premise already, the ICM of Tooby and Cosmides provided further concurrence of the elimination of the Marx-Engels premise on the foundational level, while furnishing the crucial alternative, which is based on their life time of factor analysis theoretical framework building in biology and narrow evolutionary psychology and interaction with the disciplines of anthropology, paleontology, and social psychology.

The ICM fit the selection criteria of the IEM under construction at is it was: (a) a gender differentiated foundational base from evolutionary theory that is based directly on the natural selection process of Darwin 1859 and 1871. In addition, (b) their ICM merges with the gender differentiated psychological personality theories of the post Freudian era as well, which use the core-periphery method of modeling which is a parallel integrative methodology in the value neutral bifurcated proper and perverted form dichotomy of Aristotle.

This combination of goals, combine to achieve the major objectives of Gintis, all with a series of off-the-shelf frameworks, which require only slight modification to laterally integrate. In this sense, there is nothing new about this model, other than the overarching research design that identifies, selects and integrates existing frameworks into a singular schema, after eliminating the MarxEngels premise on all three foundational, political and economic levels across the board.

\section{The Two Competing Foundations of the Human Studies Disciplines}

The thorough explanation of the two competing foundational premises of the entire philosophical and social sciences are presented in detail by Tooby and Cosmides in their essay entitled The Psychological Foundations of Culture, 1992, and should be read and understood by anyone interested in interdisciplinary theorizing. (The PDF of the essay is on line at UCSB (http://www.cep.ucsb.edu/papers/pfc92.pdf)). It is crucial to understand that there are only two 
foundational premises in the entire human studies and the Marxian premise is laughably false, but clung to in the soft social studies like a security blanket, stunting the growth of multiple disciplines simultaneously for the reasons states by Tooby and Cosmides and Gintis.

The essential elements of the essay of Tooby and Cosmides is that they first explain how logically coherent the physical sciences are. The physical sciences of physics and engineering have frameworks that operate from similar principles of gravity, atmospheric pressures, molecular density pertaining to the strength of materials et cetera. The use of interlocking theoretical frameworks represents the means by which designers and engineers from neighboring disciplines can working on a singular project that will actually work without endangering the user, and produce a working product that consumers will buy repeatedly.

In direct contrast are the philosophical and social sciences. Tooby and Cosmides discuss that the social sciences are logically incoherent and chaotic as each discipline is completely disconnected from the neighboring disciplines under the guise of freedom of speech and academic freedomand totally ignoring the concept of interoperability.

The result is that the only disciplines that advance theoretical schematic type frameworks is the field of economics and demography as Harsanyi and Gintis explain in detail. The remainder of the human studies ceased the scientific projects during the 1970s as Tooby and Cosmides.

They explain this assertion from their point of view in Evolutionary Theory as it relates to Social Psychology, and Anthropology and paleontology. Allan Bloom concurs and explains this same phenomenon from his point of view in Political Philosophy in The Closing of the American Mind (1988), and a contributor to the Strauss-Cropsey text as the result of Leftism and their zeal to rid the human studies of objective measures and standards that would differentiate class and gender differences that would interfere with their ideal of equality. The decontructionalist movement set out to rid the social sciences of "objective measures and standards" as mere arbitrary preferences to maintain the system of oppression represented by the patriarchal capitalist system as explained by Leacocke in her forty-four page introduction to The Origin of the Family, the Private Property and the State (Engels 1884). It is her introduction that explains in long detail why the feminist movement adopts the Marxian premise as their foundational hypothesis.

\section{Historicism, Psychologism, Post Modern Deconstructionalism and the SSSM}

Tooby and Cosmides attribute this problem to the lack of scientific methodological standards, under what they refer to as the autarkic and chaotic Standard Social Scientific Model (SSSM). The autarkic SSSM is based on the Marxian hypothesis that men and women have no innate difference in instinctual drives, and therefore can be infinitely malleable by external familial, religious, educational, political and economic institutions to achieve equality.

In their minds, since humans are infinitely malleable, there would be no fixed schematic frameworks of human rational actor predictability, so therefore, there is no reason to continue the scientific project of human behavior in relationship to an ideal state. Instead, the ideal state is attained by the control of the educational and informational institutions that would bring about the historical inevitability of Socialism via the method of mass "psychologism" advanced by conformist theories in the field of sociology during the $20^{\text {th }}$ Century. 
The Marx-Engels premise, The Origin of the Family, and discussed in the previous papers, was that property rights and marital rites are artificial constructs of patriarchal dynasties supported by religious institutions to subjugated other males into a class hierarchy via the institution of property rights, whereas marital rites were created to subjugate females for the purposes of paternity certainty. Therefore, for humans to return to the alleged equality that existed in the state of nature, both property rights and marital rites had to be eliminated from all cultures in general, and Western Culture specifically since it had become technologically advanced, geopolitically powerful, and was exporting Christianity and capitalism.

It is this premise of achieving total equality that has driven Marxist thought in both the sense of non market Communism where Marxism was to be gained by violent revolution, and Social Democracy based on cultural Marxism and a peaceful incrementalist approach over time. With Communism failing, the means has drifted to highly redistributive Social democracy, based on equality of outcome, and the fervent belief that in a few generations, can replace Capitalism, and turn mere mixed economies into a Socialist utopia. With the elections of Obama in the United States, and Trudeau in Canada, and the popularity of Bernie Sanders in the last election, the Left now realizes that the long march through the institutions is almost completed, and the psychologism of the masses will occur. Scientific models are completely unnecessary.

\section{The SSSM, the anti Behavioral Science trend as a form of elite-elite competition}

The post-modern philosophy espoused by Derrida has gravitated toward this line of thinking en masse. It has no basis in reality as its foundational premise if false, it failed on several levels in non market Communist experiments, and it has proven to be a destabilizing ideological belief under high population growth conditions repeatedly during the $20^{\text {th }}$ Century.

What it provides however, is for the professors in the soft social sciences a means of establishing control over a bourgeois system that otherwise does not need them. It is easy to establish this self-interested motive when one considers how far Left the soft philosophical and social sciences professors have become in direct comparison to the business school majors of economics, finance and accounting that directly support the bourgeois system.

Furthermore, this movement of deconstructionalism, based on the Marx-Engels foundational premise, has been almost universally adopted by the feminist movements as explained by Leacocke in her introduction to the reprint of The Origin of the Family, that she assigned as her course in women's studies in New York. Since then, the deconstructionalist premise expanded from the Marxist and feminist bases and has become the basis for the myriad of soft social sciences advancing ethnic studies and identity politics messages today, which is how the author became familiar with this line of literature.

Tooby and Cosmides discuss in explicit detail how this hypothesis is laughably false, but are apparently unaware of exactly where it comes from. They are acutely aware of the effort to search for matriarchal societies in primitive societies as the means of proving the Marx-Engels hypothesis to be correct.

Tooby and Cosmides explain in detail how this effort has led to dubious literature gained from studying primitive South Pacific island cultures such as Margaret Meade (19XX), which proved to be false by subsequent investigators. In addition, Tooby and Cosmides explain how the discipline 
of social psychology has been advancing this premise since the 1970s and is supported by contrived class room experiments that are designed to rebut, or debunk work published in the field of biology and narrow evolutionary psychology, particularly concerning the differences pertaining to male and female jealousies and the tendency of females to pursue men of wealth, power and fame.

However, in today's information age, where statistics on male and female purchasing trends is instantaneous, and court records are plentiful showing the types of crimes men and women tend to commit, and the motives regarding the reasons why men and women divorce, combined with the immense data from the fashion and jewelry industries, there is ample empirical evidence to prove Fromm's 1955 assertion that men and women market themselves as they compete for resources and mates in the ongoing context of self-survival and survival of the species.

Hundreds of thousands of years of selection pressures have formed domain specific hardwired drives of humans and are highly resistant to the psychologism into anything close to a socialist utopia. If it had validity, then the developing world could have been psychologized into lowering its birthrates decades ago. And had population growth remained a constant, as opposed to the rampant variable that it is, there would be no Third World countries today, there would simply be a collection of First World nations.

The age of real time purchasing statistics makes it possible to easily affirm the gender differentiated theories of the post Freudian psychological theorists that advanced the gender differentiated hypotheses and bypass what Gintis refers to as the 'nanomodels' of the current discipline of social psychology where they depict "highly specified aspects of human behavioral with no analytical linkages between them." If the field of social psychology could build scientific models to support the Marx-Engels thesis they would adopt scientific procedures, but since they cannot, they are in a permanent debunking mode as the discipline of foundational, and political philosophy are also stuck in.

\section{Deconstructionalism and Feminism}

For the reasons explained in Leacocke's introduction, the Marx-Engels thesis has become the theme of Derrida's deconstructionalism in the field of philosophy, as well as much of the writing from the structural functional school in Sociology, anthropology and paleontology, and of course, feminist studies. The theoretical problem as explained by Tooby and Cosmides is that this thesis that ancient societies were matriarchal: (a) has no supporting evidence anywhere at anytime; (b) cannot account for the learning of culture to fuse the three aspects of the human psyche of: (i) life-force energies, (ii) instinctual drives and (iii) cognition in terms of the psychological model being introduced in this series of writings, or Freud's three psychical element model of Id (instinctual drives), Ego (immature cognition) and the super ego (the mature educated cognition); and (c) the domain general infinitely malleable premise cannot account for male and female sex drives that explain for the survival of the species to and answer the question of why humans exist today, and why the two trends of technology and population growth are persistent.

This series of understandings this leads to (d) that the Marx-Engels premise adopted by the post modern deconstructionalist movements, which dominates the soft studies areas of the philosophical and social sciences, are completely unable to link their theoretical frameworks to merge with the natural selection process as defined by Darwin 1859 and 1871. 
As a result, (e) the Marxian foundational hypothesis cannot link the two disciplines of Darwinian evolutionary theory to any post Freudian psychological theories to conjoin the innate instinctual drives discipline to the environmental shaping disciplines. As discussed in McMillan 2015, it has already been explained why the political and economic aspects of the Marx-Engels hypotheses can be disconfirmed. The sum of (a) through (e) is that almost the entire field of philosophy and the soft social sciences are now in a permanent debunking mode and cannot move forward for the reasons expressed in this series of papers, that advances the conclusions of Harsanyi, Streauss and Cropsey, Tooby and Cosmides, Vernon Smith, and Gintis.

In concluding this section, the adoption of the Marxian domain general table rasa infinitely malleable foundational premise, combined with the adoption of the value neutral only form of modeling from the structural functionalist schools, as opposed to the value neutral bifurcated proper and perverted Forms of modeling of Aristotle, combine to account for the logical incoherence of the post Modern Era of Derrida's deconstructionalism, and the inability of the social sciences to determine an overarching causal theme, and integrative methodology, and compatible frameworks required to move forward.

\section{Answering Gintis}

The answer to Gintis is that all three of the barriers to developing a unification of the behavioral sciences has existed for decades, all one has to do is return to the pre 1970s frameworks before the anti 'objective measures and standards' movement took control of the soft philosophical and social sciences as explained by Bloom.

Derrida's decontructionalism in the discipline of philosophy, and the structural functionalist approach in sociology and political science movement of the mid to late $20^{\text {th }}$ Century has created the problem of the logically incoherent Standard Social Scientific Model (SSSM) that now has the philosophical and social sciences permanently stuck in a debunking mode.

This logical incoherence will persist in the majority of the soft philosophical and social sciences as long as stay tied to the Marx-Engels premise, do not return to the proper and perverted Form behavioral dynamic integrative methodology, and avoid adopting scientific procedures in performing autopsies on the failure of Nonmarket Communism and Latin American Socialism under the conditions of high population growth exceeding economic and job growth.

As was presented in 2015 and McMillan August 2017, an integrated explanatory model that integrates the three primary areas of psychology, political and economic theory in a complete model, was easily achieved by the comparison of the Hume-Smith versus Marx-Engels foundational-political-economic philosophical theories.

The examination of the competing Hume-Smith versus Marx-Engels foundational-politicaleconomic hypotheses against the real life experiments of free market Capitalism versus non market Communism confirmed the basis of the Hume-Smith model. The Hume-Smith model, with the gender differentiated ICM of Tooby and Cosmides proved to be easily updatable by a series of confirmed empirical post Freudian, psychological frameworks, which easily merge with Aristotle's six forms of government, and macroeconomic theories represented by the per capita 
GNP ratio simplification signifying the economic growth indicators in proportion to the demographic rates of change.

It was this series of micro and macro behavioral frameworks that achieved the integrated explanatory model (IEM) of Harsanyi 1960 and merges with the ICM of Tooby and Cosmides as the foundational base. The expansion of the original research design to the meet the criteria of Harsanyi led to the unified theory of the micro and macro philosophical and social sciences in a format to become the IEM of Harsanyi, which extend the ICM of Tooby and Cosmides throughout the rest of the human studies areas when combined.

This combination of an IEM that merges with the ICM overcomes the three barriers of achieving a unification of the micro and macro behavioral sciences as expressed by Gintis as being: (1) the lack of an identifiable overarching casual theme, (2) the lack of an integrative methodology, and (3) the lack of identifiable compatible frameworks, while (4) the behavioral dynamic approach of this model is based on the idea that rational actors pursue a course of action to best pursue resources and mates, or economic gain and social status, all in accordance with changing policies that occur within the two overarching trends of technology and population growth. It concurs with Gintis, that the rational actor belief, preference constraint model is certainly applicable to all three of the primary philosophical and social sciences areas of psychology, politics and economics. It therefore pertains to the secondary disciplines as well.

\section{Strauss and Cropsey}

In guiding this paper toward a conclusion, a series of points need to be made.

First, all of the major abstract concepts of operationalizing the nomos-physis distinction and defining noumena and phenomena can be operationalized into a Carteisan modeling format.

This is achieved as the unseen forces of nature alluded to by Socrates and Plato I his concept of Forms, were finally defined in terms of the dual Darwinian motivations of self-survival and survival of the species. These noumenal unseen forces become observable by the pursuit of resources and mates in anthropology, and economic gain and social status in political economy. These activities then become the basis for understanding the constructive versus destructive behavioral continuums of the psychological, political and economic frameworks chosen in the dual independent variable system expressed in McMillan 2015, and briefly outlined earlier in this paper. This lead to the conclusion that if the abstract concepts of the Strauss and Cropsey can be represented in a Cartesian style model, then the Fifth Era of philosophy has begun-with or without the assistance from the discipline of philosophy itself.

Secondly, had the discipline of Philosophy followed the scientific method of Dewey, there never would have been a post modern Era of Derrida in the first place. As the Great Ideological Experiments of the 20th Century were under way and concluding, the field of Philosophy should have been in the reassessment and reformulation phase explained in the Dewey section of the Strauss-Cropsey text, or the original work Reconstruction in Philosophy (1921).

Theoretically, in hindsight, the field of philosophy should have been comparing and contrasting the foundational, political, economic hypotheses of the only two teams to develop a coordinated three level philosophical theory all along. The hypothesis formulation phase of the scientific 
method was already done by Hume and Smith versus Marx and Engels models. Had the discipline of philosophy aligned the major works of competing foundational, political and economic thinkers according to their areas of expertise, the field would be farther ahead in terms of perfecting a systematic assessment phase.

The second phase should have been the testing and observation phases done in real life experimentation since the Bolshevik Revolution of 1917, which concluded in the early 1990s with the non-market economies converting to market economies for the reasons expressed earlier in this paper, and further explained in McMillan 2015.

The third phase of the scientific method began with McMillan 2015 and is progressing with the series of papers presented in 2017, represents the attainment of this third phase of the scientific method, which is the reassessment and reformulation phase. This reassessment and reformulation phase, by definition accounts for the Fifth Era of philosophy. And referencing Heidegger, the purpose of this model put forth in this series of papers, is for it to go through the same three phases of methodological investigation, refinement, and supersession over time, as the world is in a continual state of Becoming.

\section{The Soft Social Sciences and Freud's Seven Defenses}

Thirdly, after the ideological experiments the range of foundational-political-economic hypothesis should have shrunk twice. This point cannot be overstated as to its importance. First, the Capitalism versus Communism experiment eliminated the Marx-Engels ideological theory in one sense, while it also ended Communism as a viable 'end of history' in terms of trend line projection analysis. (and yes, Philoosphy can go into mathematics because this aspect if a trend projection analysis problem.)

In addition, the second reduction of the range of valid ideological theory, as will be dealt with in the series of papers being presented with IISES this year, is that the viability of market socialism should be severely reduced as well. In repeated experiments, in both Latin America and in India, where population growth outpaces economic growth and job growth, market socialism merely becomes an ideology of financial, economic and then political instability.

Where the primary axis continuum set compared the Hume-Smith versus Marx-Engels models to eliminate the Marx-Engels model and affirm the Hume-Smith model, the outcome measure submodel focuses on comparing economic to population growth ratios of competing modernization theories to further narrow the range of viable ideologies and their relationship to government Forms.

From this initial assessment, so far it appears that stable democracies only exist with a high economic growth and low population growth ratios that produces a tight wage labor market scenario, and therefore a high level of relative equity. Any other conditions tend, i.e. high population growth loose labor low relative equity scenario, tends to lead to an oscillation between the proper and perverted forms of the rule of the few, i.e. Aristocracy and Oligarchy. Aristotle's Six Forms of government may have to be updated in terms of its language, but it is still highly explanatory if defining exactly how many government Form categories are indeed possible, and how constructive elite versus elite competitions lead to the Proper Forms of government, and destructive competitions tend toward the perverted Forms of government. 
The investigation here supports the thesis that countries need to gain a certain level of economic growth in relationship to population leveling in order to attain a tight wage labor market measure of income equality prior to expanding suffrage. It appears that any premature movement towards democracy under loose labor market high inequality scenarios, tends to create the conditions where the voters vote themselves entitlements to redress inequality-as opposed to the objective of creating a constructive behavioral economic dynamic instead.

This course of action, instead of culminating in a stable condition of equality, has repeatedly ended up in diverting investment to consumption, and replicates the Latin American Death Spiral of slowing the economic growth elements in the numerator of the per capita GNP ratio, encouraging population growth in the denominator, which moves the proportions of economic growth and population growth in the wrong directions creating a looser labor market scenario, and the cascading effect of financial, economic, and political series of instabilities. Venezuela with all of its oil wealth, is going through this today, where a Socialist leader was voted in through the democratic process, and looted the system rather than (a) creating a constructive economic dynamic, and (b) bringing their population growth into proportion with their economic growth dynamic.

\section{Explaining the modification of the First, Second and Third World classification system}

Fourthly, as was briefly mentioned in the outline, the basis of the dependent variable outcome measure sub-model was to further link the behavioral model of the primary $(X, Y, Z)$ axis continuum set to the two trends of technology and population growth. This was done by modifying the subjective three category First, Second and Third World country classification system into a Four Category system.

This four-category system is based on the idea that the vertical Y2 axis would be based on a low to high economic growth continuum, in relation to an horizontal X2 axis based on low to high population growth continuum over time. The horizontal Z2 axis then becomes a low to high human capital continuum dichotomy. The purpose of this is to link the psychological simplification already used in the discipline of economics to the complex behavioral system expressed in the HumeSmith versus Marx-Engels comparison, and further defined dual independent variable selection of the psychological, political and economic frameworks.

In short, the system is based on the ICM of Tooby and Cosmides, as it relates to the coreperiphery modeling of Maddi and the productive versus sadomasochistic relationship Form dichotomy of Fromm 1972, as this micro behavioral series of frameworks links to the macro organizational frameworks of Aristotle's Six Forms of government as it relates the per capita GNP ratio simplification of neoclassical economic theory. This sequence covers the individual psyche, family and small group relationship Forms, as it relates to the macro behavioral disciplines of political and sociological institutional theories, and macroeconomic theory.

In other words, since the complex economics and demographic mathematics and statistical models were reduced to the per capita GNP ratio simplification and the two central determinants of the multiplier and gini coefficients to allow the author could concentrate on building a complex behavioral model to compliment the complex mathematical and statistical models already in use 
by the disciplines of economics and demography, it can be said that the disciplines of economics and demography had been using the human capital simplification as a place holder until a more complex behavioral model could be developed.

In this line of reasoning, the outcome measure submodel is a means of conjoining both systems, and utilize the existing frameworks across the full spectrum of the philosophical and social sciences. The primary model and outcome measure submodel are designed to be symmetric compliments where the primary model is used to better understand the constructive behavioral dynamic of the United States as opposed to the destructive behavioral dynamic for resources and mates in the Marxist Communism first, then uses that knowledge and model to understand why the ideal of equality is a false objective and leads to a destructive behavioral dynamic, especially under the conditions where population growth outpaces population growth. While this will be the topic of future works, Socialism, and the human idela of equality as a primary goal, often mimics the perverted government form low investment characteristic of the Oligarchies and Tyrannical cleptocracies.

\section{Utopia-dystopia, equality-inequality, and stability-instability continuum models}

Fifthly, the outcome measure application submodel suggests that under a one world political economy characterized by free trade, the offshoring od manufacturing jobs from developed to developing countries, combined with an open borders open societies policy to increase global interdependency and cohesion, which are all occurring under the conditions of high population growth, means that the market theory of wage labor determination will be the dominant theory of explaining the future in terms of an equity-disequity, utopian-dystopian, or stability-instability model.

With a rampant population growth conditions, and Developed country manufacturing moving to the developing world to (a) move closer to the raw materials and add value added employment to the developing world as advocated by Prebisch-Singer theory; and (b) move to the developing world with rampant overpopulation to take advantage of the large labor pool and low wages; and (c) due to the lower wages and costs, the multinational corporations can produce products at a price point that an emerging market can afford, then (d) it makes no sense to build new factories in both the developed and developing world, when they can just build larger factories in the developing countries and ship back to the developed world at higher profits.

Under this trend of common sense, the developed countries are un-developing, while the developing countries are exporting their rampant excess population growth to the developed world. In this combination of manufacturing jobs going one way, and migration going the other, that an equilibrium is occurring.

In this sense, it is the direction of this equilibrium that determines whether or not the world is moving toward a utopian future or a dystopian future, based on whether the world is moving towards higher levels of income equity or lower levels of income equity, or becoming increasingly stable, or increasingly unstable in respect to the two persistent trends of technology and population growth. 
In other words, as the market theory of wage labor pricing suggests, there will be a continued decline of First World wages as the First, Second worlds merge with the wage labor rates of the Third World, and Fourth World failed states. What is problematic is that with the burgeoning populations as depicted by the charts, there will be no 'bottoming out' in the near future where population growth ceases, and economic growth increases, to the point where a global tight labor market will exist and push up prices globally.

When placed into the context of the financial indebtedness of the developed countries, the combination of national debt, state debt, local debt, with mounting unfunded liabilities for pensions, entitlements, health care and other social services, in context of mounting personal credit card, student loan debt for social sciences degrees unrelated to any job skills, automobile and mortgage debt, there will be no global bottoming out and rebounding of the global wage labor market price prior to the point where Developed countries will more than likely become financially insolvent, and economically and politically unstable.

The most likely scenario is that as population increases rampantly, and the offshoring of manufacturing jobs increases, along with corporate inversions, a global loose wage labor scenario will persist and so will income disparity. Combined with the concurrent trend of the social sciences inculcating the educational, mass media communications feed back loop with the false correlation that since market economies exist, and so does inequality, the cause must be capitalism and the remedy is socialism.

In reality, as this framework of analysis suggests, democracies of self-governing people exist under a series of psychological, political and economic optimums, one of which is a tight labor market high sectoral development set of conditions, all existing simultaneously. Currently, as this framework of analysis suggests, population growth is grossly outstripping economic growth, job growth and scarce resources ion a global scale. The false cause and effect relationship derived from the Marxist spurious correlation of market economies, inequality, and the fix of socialism, will more than likely lead to a scenario, that as income disparity rises as the loose labor market scenario increases globally, the socialist message will resonate, leading to a socialist prescription.

Following this line of reasoning in a rational actor belief, preference and constraint model scenario, the most likely scenario is for the have nots in a democracy to follow the socialist prescript and vote themselves more money for the purposes of equality, and ending the global system of capitalist oppression.

The most likely result of this rational actor belief preference and constraint course of action will be a diversion of investment monies via taxation and redistribution, which will slow down economic growth in the numerator elements of the per capita GNP ratio, while encouraging population growth in the denominator element of the per capita GNP ratio, thus moving both functions in the wrong direction exasperating the problems of economic growth, equality and stability.

In concluding this line of thinking, the most likely scenario under the two trends of primary technology and population growth, and the two sub trends of offshoring First World manufacturing 
jobs, and developing world rampant population growth, is for the developing world to experience the Latin American Socialist death spiral themselves.

Greece has in effect gone through this death spiral already, but so far has been bailed out by the European Union. However, Italy, Spain and Portugal also have high levels of debt, while the UK, Germany, France and the Benelux countries all fear the mounting sum of unfunded pension liabilities will not be able to be paid for by the declining population.

This is problematic as they are now relying that the migration of less educated from the low human capital Fourth World will be prosperous enough to support and maintain the system, rather than be a net expenditure. As this model indicates, democracies based on a mixed economy, or heavy redistributive Socialist societies, all rest on a series of psychological, political, economic and demographic rates of change optimums, and it is difficult to see how that combination of optimums will be maintained, especially since the soft social sciences argue that they are arbitrary preferences that do not exist.

But if there is not a system of balances governed by the tight versus loose market theory of wage labor determination, then now does one explain why democracies exist in some places and fail dismally in others? How does one explain the differences between developed and developing countries, and why most developing countries persist since technology and know-how has been exported from developed to developing countries for an entire century? The perpetual 'developing' countries should be referred to as the perpetually overpopulated countries as a more accurate term that reflects a more honest sense of causation.

\section{Meeting the physics modeling format}

Sixthly, in the conclusion to this paper, it is explained how a primary set of triple casual axis continuums is derived, and a dual independent series of psychological, political and economic behavioral frameworks, links to a triple axis continuums submodel and operationalizes the concept of equality into a belief preference constraint rational actor model for the soft social sciences.

The significance of this series of steps, was to is to meet the last criteria of Gintis that a unification of the behavioral sciences should lead to a rational actor belief preference constraint model accomplished in the last section, which then sets the stage to meet further objectives of Tooby and Cosmides and Strauss and Cropsey.

It was written in the Tooby and Cosmides essay that the social sciences should be patterned after the physical sciences. In the physical sciences, it is typical to relate two forces of nature directly to a four or five element success-failure parameter model. In aeronautics, this translates into relating the two forces of gravity and atmospheric density to the four elements of thrust, lift, weight and drag.

In this sense, the relationship of the first force is to meet the primary objective of getting the aircraft airborne. Whereas the purpose of the second force is to optimize the four elements of the success-failure parameters to the end user optimization requirements. For example, a cargo plane optimizes lift with the trade-off being terminal speed and range. Likewise, a passenger 
airliner that does not have to carry as much weight in payload, will use a thinner profile wing, reduce lift, but reduce drag, and therefore optimize speed, fuel economy and range, with the same set of engines as a constant in the example.

Infinite variations exist as there are types of aircraft and user needs, and operational environments, but the point is to establish a two force primary variable set, as it relates to a four element success failure set of parameters that represent a pareto-style set of equilibriums and optimums that reflect a series of trade-offs and opportunity costs which was a major criteria of Harsanyi. This can now be achieved by subsuming both the primary axis continuum set, and the dual independent variable set, and the secondary outcome measure axis continuum set, by subsuming it under the tow overarching variables of Being and [changes in form] over Time.

The significance of this is to operationalize the two primary variables of Heidegger's "Being and Time" with the frameworks of this system. In this sense, Being and [changes in Form over] Time is operationalized as the forces of nature are defined by Darwin and advanced by the ICM of Tooby and Cosmides. The nomos-physis variation of the constructive and destructive Forms of Plato then becomes operationalized by the psychological, political and economic frameworks of the dual independent variable system. This aspect operationalizes the major abstract concepts of the field of philosophy, where in reducing the model to its simplest form, Being and Time can be directly related to the four elements of the per capita GNP ratio that represents the resource constraint system for the soft social sciences.

This simple relationship of Being and [changes in Form over] Time as it relates to the four element per capita GNP ratio simplification represents several relationships in multiple disciplines. Initially it relates economic production/ over population growth fusing the two disciplines together in one framework. Additionally it relates economic production/political distribution, or supply/demand, or economics/n-person polity fusing together the disciplines of political theory with economics and demography in one framework as well.

In continuing this line of thinking as to what the per capita GNP ration means to this model and the discipline of philosophy, is that can signify the primacy of the Hume-Smith/Malthus philosophical enlightenment theories in explaining the nature and cause of the wealth of nations and the nature and cause of equality-inequality and poverty of nations, in one model four element ratio. Furthermore, it provides insight as to why democracies do not succeed in high population growth scenarios, and why Latin American socialism exasperates income disparity problems under high population growth scenarios, and therefore reduces the range of ideological theories.

If one examines why Nordic Socialism 'works', in contrast to Latin America Socialism, then one discovers that Nordic Socialism only 'works' within a narrow economic growth over population growth ratio. When one considers the fact that global population growth is J-Curving in the developing world, and the world's nations are seeking equilibrium in political economies, then one realizes that free trade and open borders will not yield a collection of First World countries over time, but a collection of Fourth World failed states over time.

In other words, the premise of market socialism incrementalist theory of gradually increasing entitlements and government social services as the means of increasing taxes for mass 
redistribution will not lead to greater equality, but has led to political and economic collapse and instability under high population growth scenarios. This assertion can be seen in the various Latin American Experiments, under high population growth conditions where the number of entrants into the labor force outpaces economic growth and job growth, the number of unemployed rises, and the naturally income inequality. The cause of global inequality is the Malthusian population growth problem rather than the existence of 'capitalism.'

\section{Delusions of the New Left}

The incrementalist hypothesis of Marcuse of the Frankfurt School and the New Left of the Chicago and Columbia department of sociology, is based on the idea of increasing entitlements and bankrupting capitalism as the means of increasing taxes and "evolving" the system to a socialist system. But when attempted on real human beings, what occurs is that the entitlements take money out of investment capital and slow economic growth, meanwhile the increase in the entitlement subsidies, and therefore encourages population growth.

In this reality, the economic growth elements located in the numerator of the per capita GNP ratio slows, while population growth element in the denominator accelerates. What this does economically, is that there is an increase in demand for a product, which Is not met with an increase in supply. Less is produced as people are handed more fiat currency to buy goods, leading to the hypothesis and downward Latina American Death spiral of the political economy. The problem is that the population growth is rampant in the developing world, so the equilibrium point is a bottomless pit that will lower the global wage labor rates infinitum, drastically increasing inequality in the First world to that of the developing world levels.

In this sense, the Communist end of history can be ruled out, and so can the socialist end of history as a viable ideological theory. Under high population growth conditions, socialism is a destabilizing ideologies theory, and will not be the enduring system as the Frankfurt schools wishes.

\section{Down to Adam Smith and Vernon Smith}

From the elimination of the two Marxist ideologies from contention, what is left is that the non centrally controlled premise of Adam Smith and Vernon Smith is the stable system under high population growth conditions. In this sense, the non central controller thesis affirms the autonomy hypothesis of Kant.

In distinction, the centrally planned economies, whether in the Marxist nonmarket Communist, or the Marxist socialist variants, represent the manmade heteronomous system that is contrary to human nature in terms of the nomos-physis variation and represents a destructive dynamic under high population growth situations. It simply is not going to be the deus ex machina as a utopian end of history that the true believers of socialism hope for.

As population continues to climb, the prognosis is that Western democratic nations will continue to experience wage labor inequality as manufacturing jobs continue to move abroad, corporations do inversions and transferring their headquarters abroad also, and migration increases as the trend has been for both African and Latin American populations to double every 25 to 35 years 
depending on the specific region. Under these conditions, where the masses are told repeatedly that the cause of poverty and inequality is not a population expansion over economic growth and job growth problem, but extols the spurious correlation of the existence of market economies, and the existence of inequality, and redistributive socialism will fix it as advanced by the soft social sciences, then it is reasonable to believe that the extreme debt of the First World countries due to entitlements and unfunded pension liabilities, in federal, state, provincial and local governments, and the high degree of personal credit card debt, student loan debt, mortgage and auto loan debt, it is not too difficult to imagine, under the belief, preference considerations, that the masses will vote themselves more money and send more First world nations into the Latin American death spiral and attain either Third World or Fourth World status. Under present conditions, the most likely outcome is actually the Hegelian-Malthusian end of history.

In conclusion, this singular unified theory of the philosophical and social sciences analyzes the foundational, political and economic levels of philosophical theory, and advances trend line projection analysis techniques to the competing end of history, while reducing the entire range of philosophical theirs to the two primary variable of Being and Time, to the per capita GNP ratio, as the means of linking Heidegger's concepts into economics and demographics mathematical and statistical models. This unification of the micro and macro behavioral sciences therefore attains the criteria of Okham's razor that the simplest model that explains the widest range of outcomes is the best model.

\section{References}

Aiken, Henry. The Age of Ideology: The $19^{\text {th }}$ Century Philosophers, New York: New American Library (1956)

Almond, G. and Powell, G.B. Comparative Politics: System, Process, and Policy. Boston, Little Brown and Co. (1978)

Aristotle; Politics; Translated by Benjamin Jowett, Britannica Great Books; Chicago: William Benton Publisher (1952)

Aronson, Jerold; Harre, Rom; Way, Eileen Cornell; Realism Rescued: How Scientific Progress is Possible. Open Court Publishing, Chicago, 1995.

Barkow, Jerome H.; Cosmides, Leda; Tooby, John; The Adapted Mind: Evolutionary psychology and the generation of culture, Oxford University Press, New York, Oxford (1992)

Barett, Louise; Dunbar, Robin; Lycett, John; Human Evolutionary Psychology; Princeton University Press, Princeton and Oxford (2002)

Barro, Robert J., Sala-i-Martin, Xavior; Economic Growth $2^{\text {nd }}$ edition; MIT Press, Cambridge, MA and London England (2004)

Copleston, Frederick C.; A History of Medieval Philosophy; University of Notre Dame Press, Notre Dame and London, (1990)

Copleston, Frederick; A History of Philosophy: Volume I, Greece \& Rome Part II; Image Books, Doubleday \& Company, Inc. Garden City, NY (1962) 
Darwin, Charles; The Origin of Species by Means of Natural Selection, (1859)Britannica Great Books, Chicago: William Benton Publisher, 1952.

Darwin, Charles. The Descent of Man and Selection in Relation to Sex, (1871) Britannica Great Books, Chicago: William Benton Publisher (1952)

Descartes, Rene; Discourse on Method and Related Writings; translated by Desmond Clarke, Penguin Classics, Penguin Group, London and New York (1999)

Dewey, John; Human Nature and Conduct: An Introduction to Social Psychology; The Modern Library Publishers, New York $(1922,1932)$

Dewey, John, Reconstruction of Philosophy, New York, New American Library; (1950)

Dilthey, Wilhelm; Pattern \& Meaning in History; Edited by H.P. Rickman, Harper TorchBooks, Harper \& Row, Publishers, New York (1962)

Dilthey, Wilhelm; Introduction to the Human Sciences; edited by Rudolf A Makkreel and Fritjof Rodf; Princeton University Press (1989)

Engels, Friedrich. The Origin of the Family, Private Property, and the State, New York: International Press (1884)

Engels, Friedrich. The Condition of the Working Class in England. Translated and edited by W.O. Henderson and W. H. Chaloner, Stanford, Stanford University Press (1845, T 1998)

Feris, Robert E. L.; editor; Handbook of Modern Sociology, Rand McNally \& Company, Chicago, (1964)

Feris, Robert E. L.; "The Discipline of Sociology," in Handbook of Modern Sociology, Rand McNally \& Company, Chicago, (1964)

Freemantle, Anne. The Age of Belief, The Medieval Philosophers. New York, New American Library (1954, 1957)

Freud, Sigmund. Totem and Taboo: Some Points of Agreement Between the Mental Lives of Savages and Neurotics. Translated by James Strachey. London: Routledge and Kegan Ltd. $(1950,1952)$

Frick, Willard B., Personality: Selected Readings in Theory, F.E. Peacock, Inc., Itasca, IL (1995)

Fromm, Erich, The Anatomy of Human Destructiveness, New York, Henry Holt and Company (1973)

Fromm, Erich. Marx's Concept of Man, New York, Frederick Ungar Publishing Co. 1961, 1966.

Fromm, Erich. Sigmund Freud's Mission, New York, Harper Colophon Books, (1959)

Fukuyama, Francis. The End of History and the Last Man, New York, Avon Books, New York (1992)

Gadamer, Hans-Georg; Truth and Method, Second edition, Translated by Joel Weinheimer and Donald G. Marshall, Continuum Publishing Company, New York (2000).

Gintis, Herbert; The Bounds of Reason: Game Theory and the Unification of the Behavioral Sciences; Princeton University Press, Princeton and Oxford (2009)

Gintis, Herbert; A Framework for the Unification of the Behavioral Sciences (2006) 
Gleitman, Henry. Basic Psychology, W.W. Norton \& Company, New York, $(1981,1987)$

Guthrie, W. K. C.. The Greek Philosophers: From Thales to Aristotle, New York: Harper and Row. (1959, 1975)

Harsanyi, John C.; Essays on Ethics, Social Behavior, and Scientific Explanation; Kluwer, D. Reidel Publishing Company, Dordrecht, Holland and Boston, MA (1976)

Harsanyi, John C.; "A Bargaining Model for Social Status in Informal Groups and Formal Organizations," in Essays on Ethics, Social Behavior, and Scientific Explanation; Kluwer, D. Reidel Publishing Company, Dordrecht, Holland and Boston, MA 1976; originally appeared in Originally appeared in Behavioral Science, 11 (1966), 357-369

Harsanyi, John C.; "Rational-Choice Models of Political Behavior vs. Functionalism and Conformist Theories" in Essays on Ethics, Social Behavior, and Scientific Explanation; Kluwer, D. Reidel Publishing Company, Dordrecht, Holland and Boston, MA 1976; originally appeared in World Politics, 21 (1969), 513-538

Harsanyi, John C.; "Explanation and Comparative Dynamics in Social Science" in Essays on Ethics, Social Behavior, and Scientific Explanation; Kluwer, D. Reidel Publishing Company, Dordrecht, Holland and Boston, MA 1976; Originally appeared in Behavioral Science, 5 (1960), 136-145

Harsanyi, John C.; Rational Behavior and Bargaining Equilibrium in Games and Social Situations; Cambridge University Press, Cambridge (1977)

Hall, Peter. Economics of Growth and Development, New York, St. Martin's Press. (1983)

Harre, Rom; Cognitive Science: a philosophical introduction; Sage Publishing, London 2002

Hampshire, Stuart. The Age of Reason: The $17^{\text {th }}$ Century Philosophers, New York, The New American Library $(1956,1957)$

Hegel, Georg Wilhelm Freidrich. The Philosophy of Right (1821) Translated by T.M. Knox, Britannica Great Books, William Benton Publisher, Chicago, 1952.

Hegel, Georg Wilhelm Freidrich. The Philosophy of History. (1837) Translated by J. Sirbree. Britannica Great Books, William Benton Publisher, Chicago (1952)

Heidegger, Martin. Being and Time, Translated by John Macquarrie and Edward Robinson, San Francisco, Harper \& Row $(1927,1962)$

Heidegger, Martin. What Is Called Thinking, Translated by John Gray, Perennia Library, Harper and Row $(1954,1968)$

Heidegger, Martin. An Introduction To Metaphysics, Translated by Ralph Manheim New Haven and London, Yale University Press, (1959)

Heidegger, Martin. Early Greek Thinking: The Dawn of Western Philosophy, Translated by David Farrrel, and Frank A. Capuzzi, San Francisco, Harper San Francisco $(1950,1984)$

Hobsbawm, E.J.. The Age of Revolution 1789-1848, New York: New American Library (1962)

Homans, George Caspar, "Contemporary Theory in Sociology," in Feris, Handbook of Modern Sociology, Rand McNally \& Company, Chicago (1964) 
Hjelle, Larry A.; Ziegler, Daniel J.; Personality Theories: Basic Assumptions, Research and Applications; Second Edition; McGraw-Hill International 1985.

Hume, David. An Enquiry Concerning Human Understanding. (1748) Britannica Great Books, Chicago: William Benton Publisher (1952)

Hume, David, An Enquiry Concerning the Principles of Morals; Hackett Publishing Company, Indianapolis and Cambridge, (1983) edited by, Schneerwind, J.B.

Hume, David, A Treatise on Human Nature, Oxford University Press, (2001) edited by Norton, David Fate; Norton, Mary J.

Hume, David; Essays Moral, Political and Literary, Liberty Fund, Indianapolis (1987) edited by Miller, Eugene F.

Husserl, Edmund. "Philosophy as Rigorous Science." Translated with introduction by Quentin Lauer, in Edmund Husserl, Phenomenology and the Crisis of Philosophy; New York: Harper and Row, 1965

Issak, Alan C.. Scope and Methods of Political Science.; Wadsworth Publishing Company, Belmont, CA $(1969,1985)$

James, William. The Principles of Psychology, 1890, Britannica Great Books, Robert Maynard Hutchins, editor in chief, (1952)

Kant, Immanual; Critique of Pure Reason, in Kant Selections, edited by Lewis White Beck; Prentice Hall, Upper Saddle River, NJ (1998)

Kant, Immanual "Fundamental Principle of the Metaphysic of Morals", Great Books of the Western World vol. 42, William Benton Publisher, Chicago, (1952)

Kant, Immanual; The Critique of Practical Reason", Great Books of the Western World vol. 42, William Benton Publisher, Chicago, (1952)

Kant, Immanual; Eternal Peace; in The Philosophy of Kant's Moral and Political Writings' edited by Carl J. Friedrich; The Modern Library, New York (1949)

Kalat, James W.. Introduction to Psychology, $4^{\text {th }}$ edition, Pacific Grove, Brooks/Cole Publishing Co. (1996)

Kindleberger, Charles. Manias, Panics, and Crashes: A History of Financial Crisis. New York, Wiley Press, $(1978,1996)$

Kindleberger, Charles P.; The World in Depression, 1929-1939. ; University of California Press, Berkely and Los Angelos (1973)

Kindleberger, Charles P.; Comparative Political Economy: A retrospective; MIT Press, Cambridge, MA and London, England (2000)

Kindleberger, Charles P.; International Economics, $4^{\text {th }}$ edition; Richard D. Irwin, Inc., Homewood, IL (1968)

Kirchner, Walther. Western Civilization Since 1500. New York: Barnes and Noble, $(1958,1962)$

Lampert, Laurence,. Leo Strauss and Nietzsche, Chicago, University of Chicago Press (1996)

Lasswell, Harold D.; Psychopathology and Politics; The Viking Press, New York 1930 
Lindblom, Charles Edward, Politics and Markets: The world's political economic systems. New York, Basic Books. 1977.

LeKachman, Robert. The Age of Keynes, New York, Vintage Books, 1966.

Macridis, Roy C.; Contemporary Political Ideologies: Movements and Regimes; $5^{\text {th }}$ edition; Harper Collins Publishers (1992)

Malthus, Thomas Robert; An Essay on the Principle of Population; edited by Philip Appleman, A Norton Critical Edition, W.W. Norton \& Company, New York and London (2004)

Maddi, S. R.. Personality Theories: A Comparative Analysis, Homewood, The Dorsey Press, 1972.

Maddi, S. R. ibid, 6 ${ }^{\text {th }}$ Edition, Brooks/Cole Publishing Co., Pacific Grove, CA 1996

Marx, Karl. Das Kapital, Translated from the third German edition by Samuel Moore and Edward Aveling. Edited by Friedrich Engels, Revised, with additional translation from the fourth edition German edition, by Marie Sachey and Herbert Lamm. Britannica Great Books, Robert Maynard Hutchins, editor in chief. Chicago, William Benton Publisher, 1952.

Marx, Karl. Pre-Capitalist Economic Formations. Translated by Jack Cohen. Introduction by E.J. Hobsbawm. New York: International Publishers, 1965.

Marx, Karl; Engels, Friedrich; The Communist Manifesto, Pocket Books, Simon and Schuster, New York, 1964

McAlister, Ted V., Revolt Against Modernity: Leo Strauss, Eric Voegelin, and the Search for a Postliberal Order. Lawrence Kansas: University press of Kansas, 1996

McCloskey, Donald N. "The Economics of Enclosure" in European Peasants and Their Markets, edited by William N. Parker and Eric L. Jones, Princeton: Princeton University Press, 1975

McKenzie, Lionel W.; Classical General Equilibrium Theory; MIT Press, Cambridge, MA and London, England (2002)

Meek, Ronald L.; Marx and Engels on the Population Bomb; The Ramparts Press, $(1953,1971)$

Montesquieu, Charles de Secondat. The Spirit of the Laws. (1748) Translated by Thomas Nugent, revised by J.V. Prichard. Britannica Great Books, Chicago: William Benton Publisher. 1952.

Myerson, Roger B.; Game Theory: Analysis of Conflict; Harvard University Press, Cambridge, MA and London, England $(1991,1997)$

Nietzsche, Friedrich. "The Use and Abuse of History," in Thoughts Out of Season, Translated by Adrian Collins. New York: Russell and Russell Inc.

Nietzsche. Friedrich. The Will to Power, Translated by W. Kaufmann and R. J. Hollingdale. New York: Vintage Books, 1968.

O'Sullivan, Elizabeth; and Rassel, Gary R., Research Methods for Public Administrators, $2^{\text {nd }}$ edition, Longman Publishing USA, White Plains, NY $(1995,1989)$

Pareto, Vilfredo; Society and the Mind, (1935) 
Petras, James. Critical Perspectives on Imperialism and Social Class in the Third World. New York, Monthly Review Press, 1978.

Plato. The Republic. Translated by Benjamin Jowett. Britannica Great Books. Chicago: William Benton Publisher, 1952.

Popper, Karl R.. The Open Society and Its Enemies: The High Tide of Prophecy: Hegel, Marx, and the Aftermath. Princeton University Press, Princeton, New Jersey. 1966, 1971

Popper, Karl. The Poverty of Historicism, Ark Paperbacks, London and New York. 1957, 1986

Popper, Karl; The Logic of Scientific Discovery; Harper Torchbooks, Harper \& Row Publishers, New York and Evanston, 1959, 1968.

Reese, W.L.; Dictionary of Philosophy and Religion: Eastern and Western Thought; Humanities Press, Atlantic Highlands, NJ 1987

Ricardo, David; On the Principles of Political Economy and Taxation (1817)

Ricoeur, Paul; Main Trends in Philosophy; Holmes \& Meier Publishers, Inc. New York and London (1979)

Riemer, Neal; Simon, Douglas W.; The New World of Politics: An introduction to Political Science, $3^{\text {rd }}$ edition, Collegiate Press, San Diego (1994)

Rostow, W. W.; Theorists of Economic Growth from David Hume to the Present; Oxford University Press, New York and Oxford, (1990)

Rousseau, Jean Jacques. The Origin of Inequality, (1755) Translated by G.D.H. Cole. Britannica Great Books, William Benton Publisher, Chicago, 1952.

Rousseau, Jean Jacques. A Discourse on Political Economy. (1755) Translated by G.D.H. Cole. Britannica Great Books. William Benton Publisher. Chicago, 1952.

Rifken, Jeremy. The End of Work: The Decline of the Global Labor Force and the Dawn of the Post-Market Era. New York, G.P. Putnam's Sons. 1995.

Rude, George. Europe in the Eighteenth Century, Aristocracy and the Bourgeois Challenge. Cambridge, Mass, Harvard University Press. 1972.

Ryckman, Richard M.; Theories of Personality, $7^{\text {th }}$ edition; Wadsworth/Thomson Learning, Stamford, CT (2000)

Sabine, George Holland. A History of Political Theory, New York: Holt, Rhinehart and Winston, 1937, 1961.

Shafer, D. Michael. Winners and Losers: How Sectors Shape the Development Prospects of the State. Ithaca: Cornell University Press, 1994.

Sheahan, Allan; Guaranteed Income: The right to economic security; Gain Publications, Los Angelos (1983)

Smith, Adam; An Enquiry into the Nature and Causes of the Wealth of Nations; Britannica Great Books of the Western World; William Benton Publisher, Chicago $(1776,1952)$ 
Smith, Adam, The Theory of Moral Sentiments; Great Books in Philosophy, Prometheus Books, Amherst, New York. $(1759,1854,2000)$

Smith, Adam; Lectures of Jurisprudence, Liberty Fund, Indianapolis, (1982)

Smith, Adam; Theory of Moral Sentiments, Prometheus Books, Amherst, NY (2000)

Smith, Gaddis. American Diplomacy During the Second World War 1941-1945, $2^{\text {nd }}$ edition,. New York, Alfred A. Knopf.

Spengler, Oswald. Decline of the West. (1917) Translated by Charles Francis Atkinson. New York: Knopf 1926, 1928.

Spero, Joan Edelman. The Politics of International Economic Relations, $4^{\text {th }}$ edition, St. Martin's Press New York; (1990)

Spinoza, Benedict de. Ethics. Translated by W.H. White, revised by A.H. Stirling, Britannica Great Books, Chicago: William Benton Publisher, 1952.

Shermer, Michael; The Science of Good and Evil: Why people Cheat, Gossip, Care, Share and Follow the Golden Rule; Times Books, Henry Holt and Company, LLC, New York, 2004.

Starr, Ross M.; General Equilibrium Theory: An Introduction; Cambridge University Press, Cambridge, New York, Melbourne (1997)

Strauss, Anselm; Corbin, Juliet; Basics of Qualitative Research: Techniques and procedures for developing grounded theory, $2^{\text {nd }}$ edition; Sage Publications, Thousand Oaks 1998

Strauss, Leo; and Cropsey, Joseph; History of Political Philosophy, Third Edition, Chicago and London, The University of Chicago Press, 1963, 1987.

Strauss, Leo; Natural Right and History, The University of Chicago Press, Chicago \& London. 1950, 1965.

Strauss, Leo: What is Political Philosophy?: And Other Studies, The University of Chicago Press, 1959, 1988.

Taeuber, Irene B., "Population and Society," in Handbook of Modern Sociology, edited by Feris, Robert E. L., Rand McNally \& Company, Chicago, (1964)

Taylor, Richard. The Empiricists: Locke, Berkeley, Hume. Garden City, Doubleday \& Company, Inc. 1961.

Tawney, R.H.. Religion and the Rise of Capitalism, Harcourt, Brace, and Company, Inc. 1926

Thomson, David. Europe Since Napoleon, $2^{\text {nd }}$ edition, , Alfred Knopf, New York (1957-1973)

Tinder, Glenn. Political Thinking: The Perennial Questions, Boston" Harper Collins, 1991.

Tiger, Lionel; Men in Groups, New York, Marion Boyars, 1969-1984.

Todaro, Michael P.. Economic Development in the Third World, $2^{\text {nd }}$. Edition., New York, Longman Press, 1992.

Tooby, John; Cosmides, Leda; "The Psychological Foundations of Culture," in The Adapted Mind; Oxford University Press, New York and Oxford (1997) 
Tucker, Robert C.. The Marx-Engels Reader, $2^{\text {nd }}$ edition. New York: W.W. Norton \& Company, 1972, 1978.

Watson, John B.; Behaviorism, W. W. Norton \& Company, Inc., New York $(1924,1925)$

Watson, John B,; Psychology from the Standpoint of a Behaviorist; J. B. Lippincott Company, Philadelphia $(1919,1944)$

White, Louise G., Political Analysis: Technique and Practice, $3^{\text {rd }}$ edition, Wadsworth Publishing Co., Belmont, California (1994) 